(c) American Dairy Science Association, 2004.

\title{
Feeding Lactose Increases Ruminal Butyrate and Plasma $\beta$-hydroxybutyrate in Lactating Dairy Cows ${ }^{*} \dagger$
}

\author{
J. M. DeFrain, A. R. Hippen, K. F. Kalscheur, and D. J. Schingoethe \\ Dairy Science Department, \\ South Dakota State University, Brookings 57007
}

\begin{abstract}
Ruminal fermentation of lactose increases molar proportions of butyrate, which is metabolized by the ruminal epithelium to $\beta$-hydroxybutyrate (BHBA). To determine the effects of dietary whey, and specifically lactose, on concentrations of ruminal and blood volatile fatty acids (VFA) and blood BHBA, 8 Holstein and 4 Brown Swiss multiparous cows ( $210 \pm 33 \mathrm{~d}$ in milk) were blocked by breed and randomly assigned to one of three $4 \times 4$ Latin squares. Treatments were control (CON; $7.1 \%$ of dietary dry matter [DM] as cornstarch), liquid whey (WHEY; 9.4\% of diet DM) containing 70\% lactose on a DM basis, low lactose (LOLAC; $7.1 \%$ lactose), or high lactose (HILAC; $14.3 \%$ lactose). Diets contained $53 \%$ forage as corn silage, alfalfa hay, and grass hay (DM basis) and a corn and soybean meal-based concentrate. Average dietary percentage of crude protein and energy density (Mcal/kg net energy for lactation) were 16.8 and 1.47, respectively. Feeding lactose increased DM intake. Milk production and composition were not affected by diet with the exception of decreased urea nitrogen in milk from cows fed lactose. Greater proportions of ruminal propionate were observed in cows fed CON relative to those fed WHEY and LOLAC. Increasing dietary lactose increased proportions of ruminal butyrate and decreased acetate and branchedchain VFA. Concurrent with the increase in ruminal butyrate concentrations, there was an increase in plasma BHBA as lactose in the diet increased. Concentrations of VFA in plasma were not affected by diet with the exception of the branched-chain VFA, which were increased in cows fed LOLAC compared with WHEY. These data indicate lactose fermentation in-
\end{abstract}

Received January 16, 2004.

Accepted April 26, 2004.

Corresponding author: A. R. Hippen; e-mail: arnold_hippen@ sdstate.edu.

*Published with the approval of the director of the South Dakota Agricultural Experiment Station as Publication No. 3402 of the journal series.

$\dagger$ This research was sponsored, in part, by a grant from the South Dakota State University Research Advisory Council. creases proportions of ruminal butyrate and plasma BHBA in lactating dairy cows; however, the observed increase in plasma BHBA is not sufficient to subject cows to ketosis.

(Key words: butyrate, ketone, rumen)

Abbreviation key: $\mathbf{C O N}=$ control diet, $\mathbf{E C M}=$ energy-corrected milk, HILAC = high lactose diet, LOLAC = low lactose diet, WHEY = whey diet.

\section{INTRODUCTION}

Lactose is the major carbohydrate (approximately $70 \%$ of DM) found in whey, a liquid by-product of cheese manufacturing. Whey also contains high-quality protein as well as major minerals such as $\mathrm{Ca}, \mathrm{P}$, and $\mathrm{K}$. Because liquid whey is inexpensive and possesses a desirable chemical composition and physical properties, it has become an attractive ingredient in diets for lactating dairy cattle for producers relatively close to cheese plants.

The ruminal fermentation of lactose and whey has consistently increased ruminal butyrate concentrations (Schingoethe, 1976; Maiga et al., 1995). Grummer et al. (1983) fed steers dried whole whey at $45 \%$ of dietary DM and reported butyrate concentrations as high as $25 \%$ of the total VFA concentration. Typically, concentrations of ruminal butyrate remain $<15 \%$ of the total VFA on an $M$ basis. Even though butyrate concentrations remain low compared with concentrations of acetate and propionate in the rumen, it is the most extensively metabolized fatty acid (70 to 90\%) during its absorption into portal circulation by the ruminal epithelium (Stevens and Stettler, 1966). Weigand et al. (1975) demonstrated that $90 \%$ of absorbed butyrate carbon is converted to ketone bodies (mainly BHBA and acetoacetate) prior to release into portal circulation. This coincides with data from Krehbiel et al. (1992), who infused butyrate into the rumen of steers and reported an increase in blood ketones and a decrease in blood glucose. As a result, the overproduction or under-utilization of ketone bodies in combination with low blood glucose would promote the onset of lactational ketosis in highproducing dairy cows, especially within the first 3 to 4 
wk after calving when feed intake is insufficient to meet the energy demands of lactation.

There appear to be differences in the observed responses between the ruminal infusion of butyrate and the heightened production of butyrate by the rumen microorganisms from the fermentation of feedstuffs such as whey or lactose. Krehbiel et al. (1992) infused butyrate ruminally and observed an increase in plasma BHBA and a decrease in glucose concentrations. Alternatively, Doreau et al. (1987) fed lactose and observed an increase in ruminal butyrate and plasma BHBA without affecting plasma glucose concentrations. These studies suggest feeding whey during early lactation may result in ruminal fermentation high in butyrate, increase blood ketones, and subsequently increase the likelihood of cows developing ketosis.

To our knowledge, the relationship between ketone body production and the feeding of whey or lactose has not been investigated. The objectives of this experiment were to determine the effect of feeding whey, specifically lactose, on concentrations of ruminal and blood VFA and blood BHBA. Our hypothesis was that feeding these products would increase ruminal butyrate concentrations without significantly affecting circulating concentrations of ketone bodies in plasma. In addition, these findings are complementary to the larger scope of our laboratory group, which encompasses the characterization of the effects of ruminal butyrate on key metabolic indicators.

\section{MATERIALS AND METHODS}

\section{Animals, Diets, and Sampling}

Eight multiparous Holstein cows (220 \pm 45 DIM) and 4 multiparous Brown Swiss cows (200 \pm 21 DIM) were blocked by breed and randomly assigned to one of three $4 \times 4$ Latin squares with 21 -d periods to evaluate the effect of feeding whey or lactose on blood metabolites and ruminal VFA. Cows were housed at the South Dakota State University Dairy Teaching and Research Center (Brookings). The first $2 \mathrm{wk}$ of each period were used to adapt cows to diets. Data were collected during the third week of each period. Animal care and use was according to a protocol approved by the South Dakota State University Institutional Animal Care and Use Committee.

Dietary treatments (Table 1) were cornstarch (Cargill, Inc., Minneapolis, MN) at $7.1 \%$ of dietary DM (CON); fresh liquid whey containing 70\% lactose (DM basis; First District Ag Service, Litchfield, MN) at 9.4\% of dietary DM (WHEY); lactose (First District Ag Service) at $7.1 \%$ of dietary DM (LOLAC); and lactose at $14.3 \%$ of dietary DM (HILAC). The CON and LOLAC were formulated to contain cornstarch and lactose, re- spectively, similar to the level of lactose found in WHEY. The HILAC was formulated to contain twice the concentration of lactose found in LOLAC and WHEY. Diets were formulated to be isocaloric (1.54 Mcal $\mathrm{NE}_{\mathrm{L}} / \mathrm{kg}$ ) and isonitrogenous (17\% CP) and meet or exceed NRC (2001) guidelines for $35-\mathrm{kg} / \mathrm{d}$ milk production. Because of the high concentrations of minerals in liquid whey, dietary $\mathrm{Ca}, \mathrm{P}, \mathrm{Na}, \mathrm{K}, \mathrm{Mg}$, and $\mathrm{Cl}$ were equalized across treatments. With the exception of WHEY, water was added to all diets to balance DM content. The liquid whey contained Myco Curb (Kemin Industries, Inc., Des Moines, IA); therefore, 100 ppm were added to all other diets on an as-fed basis.

Cows were housed in a free stall barn. Diets were mixed and fed as a TMR daily at $0800 \mathrm{~h}$ for ad libitum consumption using the Calan Broadbent feeding system (American Calan, Inc., Northwood, NH). Orts were removed and weighed once daily, and amount of diet offered was adjusted to ensure $10 \%$ feed refusal. Samples of diets were collected on d 16, 19, and 21 of each period. Cows were milked at 0600, 1400, and $2100 \mathrm{~h}$, and milk yield was recorded. Milk samples were collected on d 19, 20, and 21 of each period from all 3 milkings on each day. Samples were made into composites by day and analyzed for protein, fat, lactose, MUN, and SCC, and SNF was calculated.

Cows were weighed, and body condition was scored according to Wildman et al. (1982) immediately after the $1400 \mathrm{~h}$ milking on 2 consecutive $\mathrm{d}$ at the beginning of the study and upon completion of the experiment. Approximately $4 \mathrm{~h}$ after feeding on d 19, 20, and 21, blood samples $(\sim 15 \mathrm{~mL})$ were collected from a coccygeal vessel into evacuated tubes (Becton Dickinson and Co., Franklin Lakes, NJ) containing K-EDTA (glucose, NEFA, and BHBA analysis) and sodium heparin (VFA analysis). Blood was immediately placed on ice for transport to the laboratory. Blood was centrifuged, and plasma was harvested and stored at $-20^{\circ} \mathrm{C}$ until further analysis. Ruminal fluid was collected on d 20 and 21 of each period approximately $4 \mathrm{~h}$ after feeding by applying vacuum pressure to an esophageal tube fitted with a suction strainer. Collected fluid was immediately analyzed for $\mathrm{pH}$ using a portable $\mathrm{pH}$ meter equipped with a combination electrode. Following $\mathrm{pH}$ determination, a $10-\mathrm{mL}$ sample was mixed with $2 \mathrm{~mL}$ of $25 \%$ (wt/vol) metaphosphoric acid and frozen at $-20^{\circ} \mathrm{C}$ until analyzed for concentrations of VFA and $\mathrm{NH}_{3}$.

\section{Laboratory Analysis}

Samples of diets were dried at $55^{\circ} \mathrm{C}$ in a forced-air oven and allowed to air-equilibrate before being ground to pass a 1-mm screen (Brinkmann ultracentrifuge mill; Brinkmann Instruments Co., Westbury, NY). Samples 
Table 1. Ingredient and nutrient composition of control (CON), liquid whey (WHEY), low lactose (LOLAC), and high lactose (HILAC) diets.

\begin{tabular}{|c|c|c|c|c|}
\hline \multirow[b]{2}{*}{ Item } & \multicolumn{4}{|c|}{ Diet } \\
\hline & $\mathrm{CON}$ & WHEY & LOLAC & HILAC \\
\hline & & - & & - \\
\hline \multicolumn{5}{|l|}{ Ingredient } \\
\hline Alfalfa hay & 16.2 & 16.1 & 16.2 & 16.2 \\
\hline Brome grass hay & 3.7 & 3.7 & 3.7 & 3.7 \\
\hline Corn silage & 32.3 & 32.2 & 32.3 & 32.4 \\
\hline Whole cottonseed & 7.0 & 6.9 & 7.0 & 7.0 \\
\hline Corn grain, ground & 12.1 & 12.1 & 12.1 & 2.4 \\
\hline Corn starch & 7.1 & - & - & - \\
\hline Liquid whey & - & 9.4 & - & - \\
\hline Pure lactose & - & - & 7.1 & 14.2 \\
\hline Dried distillers grain & 7.8 & 7.7 & 7.8 & 9.1 \\
\hline Soybean meal, $44 \% \mathrm{CP}$ & 10.5 & 10.7 & 10.5 & 11.7 \\
\hline Urea & 0.26 & - & 0.26 & 0.26 \\
\hline Limestone & 0.58 & 0.92 & 0.57 & 0.55 \\
\hline Potassium carbonate & 0.65 & - & 0.66 & 0.66 \\
\hline Salt & 0.91 & - & 0.91 & 0.91 \\
\hline Dicalcium phosphate & 0.39 & - & 0.39 & 0.39 \\
\hline Magnesium oxide & 0.032 & - & 0.032 & 0.032 \\
\hline Vitamin A, D, and E premix ${ }^{1}$ & 0.194 & 0.193 & 0.194 & 0.194 \\
\hline \multicolumn{5}{|l|}{ Nutrient } \\
\hline $\mathrm{DM}$ & 48.0 & 48.9 & 48.8 & 48.9 \\
\hline $\mathrm{CP}, \%$ of $\mathrm{DM}$ & 16.8 & 16.2 & 16.6 & 16.8 \\
\hline RUP $\%$ of $\mathrm{CP}^{2}$ & 35.6 & 35.5 & 35.6 & 35.5 \\
\hline $\mathrm{NE}_{\mathrm{L}},{ }^{2} \mathrm{Mcal} / \mathrm{kg}$ & 1.47 & 1.47 & 1.45 & 1.47 \\
\hline $\mathrm{ADF}, \%$ of $\mathrm{DM}$ & 23.0 & 23.5 & 23.2 & 23.6 \\
\hline $\mathrm{NDF}, \%$ of $\mathrm{DM}$ & 33.5 & 33.8 & 32.9 & 32.1 \\
\hline $\mathrm{NFC}, 3 \%$ of DM & 36.6 & 36.7 & 37.2 & 38.4 \\
\hline Starch, \% of DM & 15.0 & 13.8 & 7.9 & 13.7 \\
\hline Lactose, $\%$ of DM & - & 5.3 & 6.1 & 13.0 \\
\hline Ether extract, \% of DM & 3.63 & 3.34 & 3.14 & 3.68 \\
\hline Ash, \% of DM & 9.25 & 9.36 & 9.92 & 9.47 \\
\hline $\mathrm{Ca}, \%$ of $\mathrm{DM}$ & 0.94 & 0.81 & 0.77 & 0.81 \\
\hline $\mathrm{P}, \%$ of $\mathrm{DM}$ & 0.43 & 0.43 & 0.41 & 0.44 \\
\hline $\mathrm{Mg}, \%$ of $\mathrm{DM}$ & 0.31 & 0.31 & 0.30 & 0.29 \\
\hline $\mathrm{K}, \%$ of $\mathrm{DM}$ & 1.67 & 1.72 & 1.67 & 1.78 \\
\hline $\mathrm{Na}, \%$ of $\mathrm{DM}$ & 0.45 & 0.41 & 0.46 & 0.28 \\
\hline $\mathrm{Cl}, \%$ of $\mathrm{DM}$ & 0.73 & 0.68 & 0.82 & 0.63 \\
\hline $\mathrm{S}, \%$ of $\mathrm{DM}$ & 0.45 & 0.24 & 0.26 & 0.25 \\
\hline $\mathrm{DCAD}{ }^{4} \mathrm{mEq} / \mathrm{kg}$ & 136 & 277 & 234 & 243 \\
\hline
\end{tabular}

${ }^{1}$ Contains 4,400,000 IU of vitamin A, 880,000 IU vitamin D, and $440 \mathrm{IU}$ of vitamin $\mathrm{E} / \mathrm{kg}$.

${ }^{2}$ Calculated using NRC (2001).

${ }^{3}$ Non-fiber carbohydrate $(\mathrm{NFC})=100-(\% \mathrm{NDF}+\% \mathrm{CP}+\%$ ether extract $+\%$ ash $)$.

${ }^{4}$ Dietary cation-anion difference as $[(\mathrm{Na}+\mathrm{K})-(\mathrm{Cl}+\mathrm{S})]$ in $\mathrm{mEq} / \mathrm{kg}$ of DM.

were composited by period and analyzed for DM, Kjeldahl N, ether extract, and ash according to AOAC methods (1997). Neutral detergent fiber and ADF were measured using the ANKOM A200 (ANKOM Technology Corp., Fairport, NY) filter bag technique. Determinations of ADF were according to AOAC (973.18 C; 1997) whereas NDF was according to Van Soest et al. (1991) with the addition of $4 \mathrm{~mL}$ of alpha amylase and 20 $\mathrm{g}$ of sodium sulfite. Dietary samples were composited across period and analyzed by Dairyland Laboratories, Inc. (Arcadia, WI) for concentrations of starch, Ca, P, $\mathrm{K}, \mathrm{Mg}, \mathrm{Cl}, \mathrm{Na}$, and $\mathrm{S}$. Starch was measured as dextrose after treating samples with glucoamylase using a YSI 2700 SELECT Biochemistry Analyzer (Application
Note \#319; Yellow Springs, OH). Minerals were quantified according to AOAC methods $(985.01 ; 1997)$ using inductively coupled plasma spectrometer (Thermo Jarrell Ash, Franklin, MA). Samples were also analyzed for lactose according to AOAC $(974.06 ; 1990)$ using an HPLC (Waters Corporation, Milford, MA) equipped with a refractive index detector and a $300-\mathrm{mm} \times 7.8$ mm column (HPX-87H; Bio-Rad Laboratories, Hercules, CA) using a flow rate of $0.6 \mathrm{~mL} / \mathrm{min}$ of $0.01 \mathrm{~N}$ $\mathrm{H}_{2} \mathrm{SO}_{4}$.

Milk compositional analysis was conducted by Heart of America DHI Laboratory (Manhattan, KS) according to approved procedures of AOAC (1990). Milk true protein, fat, and lactose were determined using near infra- 
red spectroscopy (Bentley 2000 Infrared Milk Analyzer; Bentley Instruments, Chaska, MN). Concentration of MUN was determined using chemical methodology based on a modified Berthelot reaction (ChemSpec 150 Analyzer; Bentley Instruments), and somatic cells were counted using a flow cytometer laser (Somacount 500; Bentley Instruments).

Coccygeal plasma samples were thawed, and concentrations of glucose were determined using glucose oxidase (Sigma Kit \#315; Sigma Diagnostics, St. Louis, MO) according to the procedures of Trinder (1969). Concentration of BHBA in plasma was determined (Sigma Kit 310-A; Sigma Diagnostics) following the methods of Williamson et al. (1962), and plasma NEFA concentrations were determined using a colorimetric assay (NEFA-C Kit; Wako Chemicals, Richmond, VA), following modifications by Johnson and Peters (1993). Insulin was quantified by solid-phase radioimmunoassay (Coat-A-Count; Diagnostic Products Corp., Los Angeles, CA) with an intraassay CV of 3.5\%. Plasma VFA samples were extracted using ion exchange procedures of Reynolds et al. (1986) and analyzed by gas chromatography (Model 6890; Hewlett-Packard, Avondale, PA). Volatile fatty acids were separated on a $15-\mathrm{m} \times 0.25$ $\mathrm{mm}$ i.d. column (Nukol, 17926 to 01C; Supelco, Inc., Bellefonte, PA) with a flow of $1.0 \mathrm{~mL} / \mathrm{min} \mathrm{He}$. A splitless injection port $\left(280^{\circ} \mathrm{C}\right)$ was configured with a purge time and flow of $0.10 \mathrm{~min}$ and $10 \mathrm{~mL} / \mathrm{min}$ of $\mathrm{He}$, respectively; the flame ionization detector was maintained at $300^{\circ} \mathrm{C}$. Initial oven temperature was $100^{\circ} \mathrm{C}$ for 6 min then was increased $\left(5^{\circ} \mathrm{C} / \mathrm{min}\right)$ to $120^{\circ} \mathrm{C}$ and held for $5 \mathrm{~min}$.

Ruminal samples collected for $\mathrm{NH}_{3} \mathrm{~N}$ and VFA were thawed and centrifuged at $30,000 \times g$ for $20 \mathrm{~min}$ at $4^{\circ} \mathrm{C}$. Ammonia concentrations were determined following the general protocol of Broderick and Kang (1980). Concentrations of VFA were measured by gas chromatography (Model 6890; Hewlett-Packard) using a flame ionization detector. The split ratio in the injector port $\left(250^{\circ} \mathrm{C}\right)$ was $100: 1$ with the column described and a flow of $1.3 \mathrm{~mL} / \mathrm{min}$ of He. Column and detector temperature were maintained at 130 and $225^{\circ} \mathrm{C}$, respectively.

\section{Statistical Analysis}

Weekly means of DMI and milk yield during the final week of each period were used for statistical analysis. Means were also calculated for data collected on d 19, 20 , and 21 (milk composition and blood metabolites) and $d 20$ and 21 (ruminal fluid) and used for statistical analysis. The ANOVA was conducted using the MIXED procedure (Littell et al., 1996) of SAS (2001). Cow served as the experimental unit. The model was $\mathrm{Y}=$ treatment + breed + treatment $\times$ breed + period, using cow(breed) as a random variable. Preplanned contrasts were designed to test for the linear effect of dietary lactose inclusion level (CON vs. LOLAC vs. HILAC), source of lactose (WHEY vs. LOLAC), and source of carbohydrate (CON vs. WHEY or LOLAC). Significance was declared at $P<0.05$, unless otherwise noted.

\section{RESULTS}

\section{General Observations}

The experiment was conducted during May, June, and July of 2002, and average daily temperature was $33^{\circ} \mathrm{C}$. Ingredient and nutrient composition of diets are shown in Table 1. The low CP content of WHEY was attributed to the lower than expected CP content of the fresh, liquid whey. Data from one cow during the first period were deleted and analyzed as missing data for reasons unrelated to treatment. Average BW and BCS during the experiment were $707 \pm 72 \mathrm{~kg}$ and $3.33 \pm 0.47$ and $656 \pm 65 \mathrm{~kg}$ and $3.44 \pm 0.30$ for Holsteins and Brown Swiss, respectively.

\section{DMI and Milk Yield and Composition}

Dry matter intake and milk yield and compositional data are shown in Table 2. Increasing the level of dietary lactose tended $(P=0.09)$ to increase DMI. Dry matter intake of cows fed WHEY and LOLAC were similar (22.6 and $22.3 \mathrm{~kg} / \mathrm{d}$, respectively); the greatest DMI $(23.3 \mathrm{~kg} / \mathrm{d})$ was observed for cows fed HILAC. The increase in DMI with lactose addition did not translate into an increase in yields of milk or energy-corrected milk (ECM). Average milk and ECM yields were 25.5 and $26.7 \mathrm{~kg} / \mathrm{d}$, respectively. Production efficiencies (ECM/DMI) were similar among dietary treatments. Percentages and yields of fat, true protein, SNF, and lactose in milk and milk SCC were not affected by dietary treatments; however, a breed effect $(P=0.01)$ was observed for SNF, as Brown Swiss produced milk with greater SNF relative to Holsteins (9.97\% vs. 9.51\%, respectively). Feeding WHEY decreased $(P<0.05)$ MUN relative to cows fed LOLAC (13.2 and $14.8 \mathrm{mg} /$ $\mathrm{dL}$, respectively). Additionally, a carbohydrate effect $(P<0.01)$ was observed as MUN concentrations were greater in milk from cows fed CON than in milk from those fed WHEY and LOLAC (15.1 vs. 13.2 and 14.8 $\mathrm{mg} / \mathrm{dL}$, respectively), and Brown Swiss cows yielded milk with greater $(P<0.01)$ concentrations of MUN relative to Holsteins (15.4 vs. $13.0 \mathrm{mg} / \mathrm{dL}$ ).

\section{Rumen Fluid and Plasma Metabolites}

Ruminal $\mathrm{pH}, \mathrm{NH}_{3} \mathrm{~N}$ concentrations, and VFA proportions are shown in Table 3. Dietary treatments did not affect ruminal $\mathrm{pH}$. It is important to note that $\mathrm{pH}$ values 
Table 2. Dry matter intake, milk yield, milk composition, milk SCC, BW, and BCS of cows fed control (CON), liquid whey (WHEY), low lactose (LOLAC), and high lactose (HILAC) diets.

\begin{tabular}{|c|c|c|c|c|c|c|c|c|}
\hline \multirow[b]{2}{*}{ Item } & \multicolumn{4}{|c|}{ Diet } & \multirow[b]{2}{*}{ SEM } & \multicolumn{3}{|c|}{ Contrast $^{1}$} \\
\hline & $\mathrm{CON}$ & WHEY & LOLAC & HILAC & & 1 & 2 & 3 \\
\hline & & & & & & & $P$ & \\
\hline DMI, kg/d & 21.7 & 22.6 & 22.3 & 23.3 & 1.16 & 0.09 & 0.59 & 0.52 \\
\hline Milk, kg/d & 25.7 & 24.9 & 25.8 & 25.5 & 2.40 & 0.85 & 0.58 & 0.81 \\
\hline $\mathrm{ECM},{ }^{2} \mathrm{~kg} / \mathrm{d}$ & 26.7 & 25.4 & 27.3 & 27.2 & 2.40 & 0.43 & 0.29 & 0.81 \\
\hline ECM/DMI & 1.29 & 1.20 & 1.29 & 1.18 & 0.111 & 0.63 & 0.50 & 0.69 \\
\hline Milk fat, $\%$ & 3.37 & 3.38 & 3.48 & 3.35 & 0.086 & 0.90 & 0.31 & 0.47 \\
\hline Milk fat, $\mathrm{kg} / \mathrm{d}$ & 0.89 & 0.86 & 0.93 & 0.92 & 0.085 & 0.41 & 0.27 & 0.91 \\
\hline Milk true protein, \% & 3.38 & 3.32 & 3.34 & 3.31 & 0.080 & 0.49 & 0.80 & 0.36 \\
\hline Milk true protein, $\mathrm{kg} / \mathrm{d}$ & 0.89 & 0.82 & 0.89 & 0.89 & 0.073 & 0.46 & 0.25 & 0.50 \\
\hline Milk SNF, \% & 9.81 & 9.72 & 9.75 & 9.65 & 0.137 & 0.49 & 0.85 & 0.66 \\
\hline Milk SNF, kg/d & 2.62 & 2.47 & 2.64 & 2.65 & 0.228 & 0.42 & 0.31 & 0.62 \\
\hline Milk lactose, \% & 5.16 & 5.14 & 5.15 & 5.09 & 0.119 & 0.62 & 0.93 & 0.92 \\
\hline Milk lactose, $\mathrm{kg} / \mathrm{d}$ & 1.39 & 1.32 & 1.40 & 1.41 & 0.129 & 0.46 & 0.40 & 0.72 \\
\hline SCC,$\times 10^{3} / \mathrm{mL}$ & 110 & 168 & 98 & 103 & 52 & 0.31 & 0.12 & 0.56 \\
\hline Milk urea $\mathrm{N}, \mathrm{mg} / \mathrm{dL}$ & 15.1 & 13.2 & 14.8 & 13.8 & 0.45 & 0.49 & $<0.01$ & $<0.01$ \\
\hline
\end{tabular}

${ }^{1} 1$ = Linear lactose (CON vs. LOLAC vs. HILAC), 2 = wet vs. dry lactose (WHEY vs. LOLAC), and $3=$ carbohydrate source (CON vs. WHEY and LOLAC).

${ }^{2} \mathrm{ECM}=[(0.327 \times \mathrm{kg}$ milk $)+(12.95 \times \mathrm{kg}$ fat $)+(7.2 \times \mathrm{kg}$ protein $)]($ Orth, 1992$)$.

represent samples collected using an esophageal tube and might have been contaminated with saliva. Concentrations of $\mathrm{NH}_{3} \mathrm{~N}$, total VFA, and acetate:propionate were not different among dietary treatments; however, a breed effect was observed for $\mathrm{NH}_{3} \mathrm{~N}$ and total VFA. Ruminal $\mathrm{NH}_{3} \mathrm{~N}$ in Brown Swiss cows was nearly 2-fold greater than in the Holsteins $(P<0.01 ; 6.3$ vs. $3.3 \mathrm{mg} /$ $\mathrm{dL}$, respectively), and total VFA concentrations were $20 \%$ greater for Brown Swiss relative to Holsteins $(P<$ $0.01 ; 107.6$ vs. $90.0 \mathrm{~m} M$, respectively). Increasing dietary lactose resulted in a decrease $(P<0.05)$ in $M$ proportions of acetate, isobutyrate, isovalerate, and branched-chain VFA, being least for cows fed HILAC. Ruminal fluid from cows fed CON contained a greater proportion $(P=0.02)$ of propionate relative to those fed WHEY or LOLAC (22.3\% vs. 20.8 and $20.9 \%$, respectively). Increasing dietary lactose resulted in an increase $(P<0.01)$ in ruminal butyrate proportions. Ruminal butyrate was $13.9 \%$ of total VFA for cows fed CON and $18 \%$ for those fed HILAC. Additionally, a ruminal fermentation difference was observed for starch and lactose, as feeding WHEY or LOLAC resulted in an increase in proportions of butyrate $(P<0.01)$ and valerate $(P<0.01)$ and a decrease in proportions of propionate $(P=0.02)$ relative to those fed CON.

Effects of experimental diets on plasma constituents are shown in Table 4 . Increases in dietary lactose resulted in a linear decrease $(P=0.04)$ in concentrations

Table 3. Ruminal $\mathrm{pH}, \mathrm{NH}_{3} \mathrm{~N}$, and volatile fatty acid proportions of cows fed control (CON), liquid whey (WHEY), low lactose (LOLAC), and high lactose (HILAC) diets.

\begin{tabular}{|c|c|c|c|c|c|c|c|c|}
\hline \multirow[b]{2}{*}{ Item } & \multicolumn{4}{|c|}{ Diet } & \multirow[b]{2}{*}{ SEM } & \multicolumn{3}{|c|}{ Contrast $^{1}$} \\
\hline & $\mathrm{CON}$ & WHEY & LOLAC & HILAC & & 1 & 2 & 3 \\
\hline & & & & & & & $-P$ & - \\
\hline $\mathrm{pH}$ & 6.69 & 6.68 & 6.78 & 6.68 & 0.074 & 0.92 & 0.31 & 0.59 \\
\hline $\mathrm{NH}_{3} \mathrm{~N}, \mathrm{mg} / \mathrm{dL}$ & 5.55 & 4.11 & 4.57 & 5.02 & 0.650 & 0.86 & 0.62 & 0.13 \\
\hline Acetate (A), \% & 60.6 & 59.9 & 59.5 & 57.3 & 0.64 & $<0.01$ & 0.66 & 0.25 \\
\hline Propionate $(\mathrm{P}), \%$ & 22.3 & 20.8 & 20.9 & 21.6 & 0.54 & 0.85 & 0.96 & 0.02 \\
\hline Isobutyrate, $\%$ & 0.81 & 0.67 & 0.71 & 0.53 & 0.068 & 0.01 & 0.68 & 0.14 \\
\hline Butyrate, \% & 13.9 & 16.1 & 16.3 & 18.0 & 0.38 & $<0.01$ & 0.63 & $<0.01$ \\
\hline Isovalerate, $\%$ & 1.02 & 0.94 & 1.02 & 0.74 & 0.104 & 0.04 & 0.54 & 0.71 \\
\hline Valerate, \% & 1.19 & 1.40 & 1.42 & 1.66 & 0.057 & $<0.01$ & 0.87 & $<0.01$ \\
\hline $\mathrm{BCFA}^{2} \%$ & 1.83 & 1.62 & 1.73 & 1.27 & 0.162 & 0.02 & 0.57 & 0.37 \\
\hline Total VFA, $\mathrm{m} M$ & 94.5 & 98.4 & 97.6 & 104.3 & 4.42 & 0.17 & 0.90 & 0.51 \\
\hline $\mathrm{A}: \mathrm{P}$ & 2.75 & 2.91 & 2.88 & 2.67 & 0.096 & 0.20 & 0.77 & 0.18 \\
\hline
\end{tabular}

${ }^{1} 1=$ Linear lactose (CON vs. LOLAC vs. HILAC), $2=$ wet vs. dry lactose (WHEY vs. LOLAC), $3=$ carbohydrate source (CON vs. WHEY and LOLAC).

${ }^{2} \mathrm{BCFA}=$ Branched-chain VFA. 
Table 4. Plasma glucose (mg/dL), insulin (pg/mL), NEFA ( $\mu \mathrm{Eq} / \mathrm{L})$, BHBA $(\mathrm{mg} / \mathrm{dL})$, and volatile fatty acids $(\mu \mathrm{mol} / \mathrm{L})$ in cows fed control (CON), liquid whey (WHEY), low lactose (LOLAC), and high lactose (HILAC) diets.

\begin{tabular}{|c|c|c|c|c|c|c|c|c|}
\hline \multirow[b]{2}{*}{ Item } & \multicolumn{4}{|c|}{ Diet } & \multirow[b]{2}{*}{ SEM } & \multicolumn{3}{|c|}{ Contrast $^{1}$} \\
\hline & $\mathrm{CON}$ & WHEY & LOLAC & HILAC & & 1 & 2 & 3 \\
\hline & & & & & & & $P$ & - \\
\hline Glucose & 68.0 & 67.7 & 66.5 & 65.5 & 1.5 & 0.04 & 0.38 & 0.45 \\
\hline Insulin & 150.8 & 162.0 & 122.4 & 165.0 & 30.7 & 0.92 & 0.78 & 0.28 \\
\hline NEFA & 82 & 77 & 94 & 85 & 6 & 0.32 & 0.06 & 0.63 \\
\hline BHBA & 2.01 & 2.70 & 2.55 & 3.61 & 0.30 & $<0.01$ & 0.72 & 0.09 \\
\hline Acetate (A) & 861 & 873 & 967 & 782 & 87 & 0.51 & 0.42 & 0.56 \\
\hline Propionate $(\mathrm{P})$ & 74.2 & 63.0 & 101.1 & 63.9 & 14.9 & 0.97 & 0.08 & 0.66 \\
\hline Isobutyrate & 0.80 & 0.62 & 1.92 & 0.68 & 0.43 & 0.76 & 0.04 & 0.38 \\
\hline Butyrate & 13.2 & 11.0 & 22.0 & 11.6 & 4.4 & 0.84 & 0.08 & 0.53 \\
\hline Isovalerate & 19.4 & 14.9 & 43.2 & 16.0 & 9.5 & 0.80 & 0.04 & 0.40 \\
\hline Valerate & 6.0 & 3.8 & 13.7 & 4.3 & 3.5 & 0.85 & 0.05 & 0.52 \\
\hline $\mathrm{BCFA}^{2}$ & 1.77 & 1.59 & 2.24 & 1.76 & 0.22 & 0.57 & 0.04 & 0.60 \\
\hline Total VFA & 975 & 967 & 1148 & 878 & 116 & 0.65 & 0.25 & 0.54 \\
\hline $\mathrm{A}: \mathrm{P}$ & 13.4 & 15.1 & 14.2 & 13.9 & 0.74 & 0.69 & 0.37 & 0.17 \\
\hline
\end{tabular}

${ }^{1} 1$ = Linear lactose (CON vs. LOLAC vs. HILAC), 2 = wet vs. dry lactose (WHEY vs. LOLAC), and $3=$ carbohydrate source (CON vs. WHEY and LOLAC).

${ }^{2} \mathrm{BCFA}=$ Branched-chain VFA.

of plasma glucose. This decreased plasma glucose did not affect concentrations of insulin in plasma, which averaged $150 \mathrm{pg} / \mathrm{mL}$. There was a tendency for feeding LOLAC to result in an increase in concentrations of NEFA in plasma compared with cows fed WHEY. Plasma BHBA concentrations averaged $2.7 \mathrm{mg} / \mathrm{dL}$ and increased $(P<0.01)$ in response to increases in dietary lactose inclusions. Furthermore, cows fed CON tended $(P=0.09)$ to have lower BHBA concentrations than those fed diets containing lactose. Although concentrations of propionate in plasma were not affected by level of dietary lactose inclusion, propionate tended $(P=0.08)$ to be greater for cows fed LOLAC relative to cows fed WHEY. Concentrations of isobutyrate, isovalerate, valerate, and branched-chain VFA in plasma were greater $(P<0.05)$ for cows fed LOLAC compared with cows fed WHEY.

\section{DISCUSSION}

Increasing dietary lactose from 0 to $13 \%$ (DM basis) tended to increase DMI. In other studies, feeding lactose as either liquid acid whey (Pinchasov et al., 1982) or dried whey (Schingoethe and Rook, 1976) to lactating dairy cattle also resulted in greater DMI. Similar dietary lactose levels (up to $13 \%$ lactose DM) have been fed to lactating dairy cattle (Schingoethe and Rook, 1976; Doreau et al., 1987; Maiga et al., 1995) without affecting feed intake. In addition, dietary lactose inclusions as high as 60\% (DM basis) have been fed to beef cattle (King and Schingoethe, 1983; Susmel et al., 1995) without affecting feed intake or resulting in digestive upsets; however, the number of animals used and the length of these experiments were limited, and these studies should be interpreted with caution. The greatest effect of feeding lactose appears to be its ability to alter ruminal fermentation and, therefore, blood metabolites and milk composition, not necessarily to increase DMI as observed in the present study.

The absence of any treatment effect on milk fat contradicts results of others who substituted lactose (Bowman and Huber, 1967) and dried whey (Schingoethe et al., 1976) for shelled corn in component-fed diets to cows in early lactation ( $<100$ DIM). The ability of lactose to maintain milk fat has been described by Schingoethe (1976) but is likely to be influenced by stage of lactation. Schingoethe et al. (1976) fed diets containing 3.5\% lactose on a DM basis to cows in late lactation (180 DIM), similar to the stage of lactation of cows in the present experiment (220 DIM), and did not affect milk fat.

Feeding lactose from fresh liquid whey or pure lactose did not affect milk true protein, which agreed with results from Bowman and Huber (1967) and Pinchasov et al. (1982) but not Schingoethe et al. (1976). In the latter study, feeding dried whole whey (5\% dietary DM) to replace shelled corn during late lactation (180 DIM) led to an increase in milk protein percentage over control-fed cows (3.95 and 3.80\%, respectively). Differences in response to feeding lactose and whey products could possibly be attributed to the lower dietary CP (15.8\%) and milk yields $(16.5 \mathrm{~kg} / \mathrm{d})$ in the Schingoethe et al. (1976) experiment relative to the present study (dietary $\mathrm{CP}=16.6 \%$; milk yield $=25 \mathrm{~kg} / \mathrm{d}$ ).

Regardless of amount or source, feeding lactose decreased MUN relative to CON. The whey diet was the most effective at decreasing MUN. Furthermore, feed- 
ing fresh, liquid whey decreased MUN relative to cows fed similar levels of pure, granular lactose (5.3 and 6.1\% lactose, respectively). Perhaps some of the differences observed in MUN response could be attributed to the lower dietary CP content of WHEY (16.2\%) relative to the other diets that averaged $16.7 \%$. Lactose was more effective at decreasing MUN than cornstarch when substituted 1:1 (DM basis). Effects of lactose on MUN were not a primary objective of the current study; however, these data indicate the need for further investigations to study the impact of feeding lactose on MUN, as this area remains largely unexplored.

An elegant review by Schingoethe (1976) summarized the consistent increase in concentrations of ruminal butyrate typically observed in cows fed whey. The butyrate-stimulating effect of lactose was again observed in the present study, as ruminal butyrate proportions increased with an increase in dietary lactose DM (Table 3 ). The greatest ruminal butyrate proportions (18\% of total VFA) were recorded for cows fed HILAC. This increase in ruminal butyrate was primarily at the expense of acetate, and to a lesser extent, branched-chain VFA. Other researchers have fed similar levels of dietary lactose. Chamberlain et al. (1993) and Susmel et al. (1995) fed 5 and $15 \%$ of dietary DM as lactose and found ruminal butyrate proportions of 14.5 and $13.4 \%$, respectively, which was nearly 1.5 times greater than proportions found in controls $(7.8$ and $9.8 \%$, respectively). From 1967 to 1995, there were 10 published studies reporting the effects of feeding lactose on proportions of ruminal butyrate. Ranges and (standard deviations) of the amounts of lactose fed (\% of dietary $\mathrm{DM})$ and ruminal butyrate proportions were 2.2 to $42.6 \%$ (12.5) and 6.2 to $30.3 \%$ (6.7), respectively. Studies with the greatest proportions of ruminal butyrate $(\geq 10$ percentage points over controls) were conducted using a limited number of animals ( $\leq 5$ animals per treatment). The changes in ruminal butyrate reported here are consistent with previous results.

Increasing the level of dietary lactose increased ruminal butyrate and plasma BHBA and decreased concentrations of glucose in plasma. Although our changes in plasma glucose and BHBA were not as great, these results are in general agreement with Krehbiel et al. (1992) who infused butyrate ruminally. Those researchers recorded ruminal butyrate proportions 1.5 -fold greater ( $28 \%$ of total VFA) than those observed in the present study, which resulted in an increase in plasma BHBA from 3.5 to $7.3 \mathrm{mg} / \mathrm{dL}$ and a decrease in concentrations of plasma glucose from 69.4 to $63.4 \mathrm{mg} / \mathrm{dL}$ for control and ruminally infused animals, respectively. They hypothesized that butyrate stimulated glucose utilization by peripheral tissues, resulting in decreased blood glucose. Perhaps the ruminal butyrate propor- tions in our study were not great enough to affect glucose utilization in tissues as suggested by Krehbiel et al. (1992).

These data are the first to report effects of diet-induced elevated ruminal butyrate proportions on plasma insulin concentrations. These results are similar to those of Krehbiel et al. (1992), although they infused butyrate into the rumen. A review on ketone body utilization by Heitmann et al. (1987) reported BHBA infusions at rates simulating maximum utilization in sheep $\left(0.4 \mathrm{~g} / \mathrm{kg}^{3 / 4}\right.$ per $\left.\mathrm{h}\right)$ stimulated insulin secretion and production by the pancreas. Furthermore, intravenous infusions of butyrate in sheep resulted in a dose-dependent increase in plasma insulin (Sano et al., 1995). Based on conclusions by Sano et al. (1995), because concentrations of butyrate in plasma (Table 4) were not affected by feeding lactose, it is likely that plasma insulin concentrations would remain unchanged by the amounts of lactose fed in the present study.

Feeding lactose resulted in increases in concentrations of plasma BHBA. According to data from Nielen et al. (1994), plasma BHBA concentrations $>12.5 \mathrm{mg} /$ dL indicate cows with subclinical ketosis. The greatest concentration of plasma BHBA was recorded for cows fed HILAC $(3.6 \mathrm{mg} / \mathrm{dL})$, indicating that cows were not at risk for developing ketosis. To our knowledge, only one other study has reported plasma BHBA concentrations in cows fed lactose (Doreau et al., 1987). Doreau et al. (1987) observed a 2.5-fold increase (5.4 vs. 13.5 $\mathrm{mg} / \mathrm{dL}$ ) in plasma BHBA in late-lactating cows fed $13 \%$ lactose (DM basis) from milk. Differences in results between our study and those of Doreau et al. (1987) were likely attributable to differences in experimental diets, as the later study fed a diet containing $60 \%$ hay and 10\% fat (DM basis). Poncet and Rayssiguier (1980) suggested changes in ruminal VFA $M$ proportions with lactose-supplemented diets depend on such factors as the nature of the diet, rate of intake, and rumen $\mathrm{pH}$. Although plasma BHBA concentrations were not reported by Poncet and Rayssiguier (1980), they observed an increase in ruminal propionate proportions in sheep fed $700 \mathrm{~g} / \mathrm{d}$ lucerne hay with $400 \mathrm{~g} / \mathrm{d}$ lactose compared with unsupplemented controls.

Weigand et al. (1972) suggested the enzyme system involved in rumen epithelial ketogenesis might become saturated. Our intentions were to saturate this enzyme system by feeding diets fermenting to high ruminal butyrate concentrations and increase concentrations of butyrate in plasma. Although increases in ruminal butyrate were observed, we were unable to affect concentrations of butyrate in plasma (Table 4). In addition, differences were observed for $M$ percentages of acetate and propionate in the rumen; however, concentrations of these acids in plasma were similar among treat- 
ments. In vivo data presented by Bergman (1990) found 30,50 , and $90 \%$ of ruminal acetate, propionate, and butyrate, respectively, did not appear in the portal blood. These data were in agreement with in vitro data using isolated sheets of rumen epithelium where 45 , 65 , and $85 \%$ of acetate, propionate, and butyrate, respectively, disappeared from the lumen side. That review (Bergman, 1990) emphasized the extensive metabolic activity occurring within the ruminal epithelium and partially explained the differences in VFA profiles in rumen liquor relative to those observed in plasma in the present study.

Earlier findings by Weigand et al. (1972) and Krehbiel et al. (1992), suggesting ruminal epithelial ketogenic capacity reaches a plateau with low butyrate loads (15 to $28 \%$ of total VFA), was somewhat disputed by Kristensen et al. (2000). Kristensen et al. (2000) found the extent of epithelial butyrate oxidation to be overestimated, and the portal recovery of butyrate carbon to be underestimated, if only portal net appearance rates of butyrate and BHBA are considered because of the metabolism of BHBA by the portal-drained viscera. Diet and, consequently, concentrations of ruminal VFA, $\mathrm{pH}$, and liquid volume are known to affect rates of VFA absorption (Dijkstra et al., 1993). Conclusions from Kristensen et al. (2000) were based on Leicester ewes fed a $100 \%$ forage diet and an average ruminal $\mathrm{pH}$ of 6.85, whereas Weigand et al. (1972) and Krehbiel et al. (1992) used Holstein steers fed diets containing $60 \%$ concentrate and average ruminal $\mathrm{pH}$ of 6.00 and 6.54 , respectively. Consequently, the ability to alter plasma butyrate concentrations can indeed be largely influenced by diet and, therefore, conditions within the ruminal environment.

\section{CONCLUSIONS}

Cows fed diets high in butyric acid, such as poorly fermented forages (Andersson and Lundström, 1985), or cows ruminally infused with butyrate are more susceptible to ketosis (Krehbiel et al., 1992). Although the metabolic events occurring within the ruminal epithelial tissue lead to the production of ketone bodies, largely BHBA, the connection between feeding whey, a feedstuff fermenting to butyrate, and the onset of ketosis has not been established. We hypothesized that significant increases in ruminal butyrate may induce ketosis because of the conversion of butyrate to BHBA within the rumen epithelium. Substituting dietary lactose for cornstarch in an alfalfa hay and corn silagebased diets increased proportions of ruminal butyrate and concentrations of BHBA in plasma; however, increases in plasma BHBA observed in this experiment were not great enough to place cows at risk for devel- oping ketosis. It is concluded that lactose from fresh, liquid whey or in pure, granular form may be substituted for cornstarch in diets of late-lactation dairy cows without leading to the onset of physiological conditions favoring ketosis and may improve nutrient utilization as evidenced by the observed decreases in MUN.

\section{ACKNOWLEDGMENTS}

The authors express appreciation to Kemin Industries, Inc. (Des Moines, IA) for donating the Myco Curb, to Melissa Kamperin for laboratory assistance, and to personnel at the South Dakota State University Dairy Teaching and Research Farm for the feeding and care of the animals.

\section{REFERENCES}

Andersson, L., and K. Lundström. 1985. Effect of feeding silage with high butyric acid content on ketone body formation and milk yield in postparturient dairy cows. Zbl. Vet. Med. 32:15-23.

Association of Official Analytical Chemists. 1997. Official Methods of Analysis. 16th ed. AOAC Intl., Gaithersburg, MD.

Association of Official Analytical Chemists. 1990. Official Methods of Analysis. Vol. 1 15th ed. AOAC Intl., Arlington, VA.

Bergman, E. N. 1990. Energy contributions of volatile fatty acids from the gastrointestinal tract in various species. Physiol. Rev. 70:567-590.

Bowman, R. L., and J. T. Huber. 1967. Effect of dietary lactose on milk composition and rumen volatile fatty acids. J. Dairy Sci. 50:579-581.

Broderick, G. A., and J. H. Kang. 1980. Automated simultaneous determination of ammonia and total amino acids in ruminal fluid and in vitro media. J. Dairy Sci. 63:64-75.

Chamberlain, D. G., S. Robertson, and J. Choung. 1993. Sugars versus starch as supplements to grass silage: Effects on ruminal fermentation and the supply of microbial protein to the small intestine, estimated from the urinary excretion of purine derivatives, in sheep. J. Sci. Food Agric. 63:189-194.

Dijkstra, J., H. Boer, J. Van Bruchem, M. Bruining, and S. Tamminga. 1993. Absorption of volatile fatty acids from the rumen of lactating dairy cows as influenced by volatile fatty acid concentration, $\mathrm{pH}$, and rumen liquid volume. Br. J. Nutr. 69:385-396.

Doreau, M., D. Bauchart, and A. Kindler. 1987. Effect of fat and lactose supplementation on digestion in dairy cows. 1. Nonlipid components. J. Dairy Sci. 70:64-70.

Grummer, R. R., C. R. Staples, and C. L. Davis. 1983. Effect of defaunation on ruminal volatile fatty acids and $\mathrm{pH}$ of steers fed a diet high in dried whole whey. J. Dairy Sci. 66:1738-1741.

Heitmann, R. N., D. J. Dawes, and S. C. Sensenig. 1987. Hepatic ketogenesis and peripheral ketone body utilization in the ruminant. J. Nutr. 117:1174-1180.

Johnson, M. J., and J. P. Peters. 1993. Technical note: An improved method to quantify nonesterified fatty acids in bovine plasma. J. Anim. Sci. 71:753-756.

King, K. J., and D. J. Schingoethe. 1983. Lactase activity in steers fed large amounts of dried whole whey. J. Dairy Sci. 66:1675-1682.

Krehbiel, C. R., D. L. Harmon, and J. E. Schnieder. 1992. Effect of increasing ruminal butyrate on portal and hepatic nutrient flux. J. Anim. Sci. 70:904-914.

Kristensen, N. B., S. G. Pierzynowski, and A. Danfer. 2000. Portaldrained visceral metabolism of 3-hydroxybutyrate in sheep. J. Anim. Sci. 78:2223-2228.

Littell, R. C., G. A. Milliken, S. W. Walter, and R. D. Wolfinger. 1996. SAS systems for Mixed Models. SAS Inst., Inc., Cary, NC.

Maiga, H. A., D. J. Schingoethe, and F. C. Ludens. 1995. Evaluation of diets containing supplemental fat with different sources of 
carbohydrates for lactating dairy cows. J. Dairy Sci. 78:11221130.

National Research Council. 2001. Nutrient Requirements of Dairy Cattle. 7th rev. ed. Natl. Acad. Sci., Washington, DC.

Nielen, M., M. G. A. Aarts, A. G. M. Jonkers, T. Wensing, and Y. H. Schukken. 1994. Evaluation of two cowside tests for the detection of subclinical ketosis in dairy cows. Can. Vet. J. 35:229-232.

Orth, R. 1992. Sample Day and Lactation Report. DHIA 200 Fact Sheet A-2. Mid-States DRPC, Ames, IA.

Poncet, C., and Y. Rayssiguier. 1980. Effect of lactose supplement on digestion of lucerne hay by sheep. I. Sites of organic matter and nitrogen digestion. J. Anim. Sci. 51:180-185.

Pinchasov, Y., A. Hasdai, S. Gordin, D. Katznelson, and R. Volcani. 1982. Performance of high-yielding dairy cows fed liquid whey. J. Dairy Sci. 65:28-36.

Reynolds, P. J., G. B. Huntington, and C. K. Reynolds. 1986. Determination of volatile fatty acids, lactate, and $\beta$-hydroxybutyrate in blood by ion exchange cleanup and gas chromatography. J. Anim. Sci. 63(Suppl. 1):242.

Sano, H., S. Tano, H. Takahashi, and Y. Terashima. 1995. Dose responses of plasma insulin and glucagons to intravenous n-butyrate infusions in sheep. J. Anim. Sci. 73:3038-3043.

SAS User's Guide. Statistics, Version 8 Edition. 2001. SAS Inst., Inc., Cary, NC.

Schingoethe, D. J. 1976. Whey utilization in animal feeding: A summary and review. J. Dairy Sci. 59:556-570.

Schingoethe, D. J., F. Ludens, W. L. Tucker, and S. K. Dash. 1976. Evaluation of dried whey in concentrate mixtures for lactating dairy cows. J. Dairy Sci. 59:1466-1470.
Schingoethe, D. J., and J. A. Rook. 1976. Ration digestibility and mineral balance in lactating cows fed rations containing dried whey. J. Dairy Sci. 59:992-996.

Stevens, C. E., and B. K. Stettler. 1966. Factors affecting the transport of volatile fatty acids across rumen epithelium. Am. J. Physiol. 210:365-372.

Susmel, P., M. Spanghero, C. R. Mills, and B. Stefanon. 1995. Rumen fermentation characteristics and digestibility of cattle diets containing different whey:maize ratios. Anim. Feed Sci. Technol. 53:81-89.

Trinder, P. 1969. Determination of glucose in blood using glucose oxidase with an alternative oxygen acceptor. Ann. Clin. Biochem. 6:24-27.

Van Soest, P. J., J. B. Robertson, and B. A. Lewis. 1991. Methods for dietary fiber, neutral detergent fiber, and nonstarch polysaccharides in relation to animal nutrition. J. Dairy Sci. 74:35833597.

Weigand, E., J. W. Young, and A. D. McGilliard. 1972. Extent of butyrate metabolism by bovine ruminoreticulum epithelium and the relationship to absorption rate. J. Dairy Sci. 55:589-597.

Weigand, E., J. W. Young, and A. D. McGilliard. 1975. Volatile fatty acid metabolism by rumen mucosa from cattle fed hay or grain. J. Dairy Sci. 58:1294-1300.

Wildman, E. E., G. M. Jones, P. E. Wagner, R. L. Bowman, H. F. Troutt, Jr., and T. N. Lesch. 1982. A dairy cow body condition scoring system and relationship to selected production characteristics. J. Dairy Sci. 65:495-501.

Williamson, D. H., J. Mellanby, and H. A. Krebs. 1962. Enzymatic determination of $\mathrm{D}(-) \beta$-hydroxybutyrate and acetoacetic acid in blood. Biochem. J. 82:90-96. 